\title{
RESPON KOMBINASI PUPUK KCI DAN PUPUK ORGANIK CAIR (POC) SABUT KELAPA TERHADAP PERTUMBUHAN JAGUNG MANIS (Zea mays saccaharata Sturt) DI TANAH GAMBUT
}

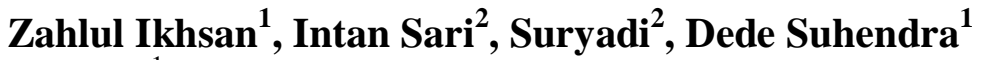 \\ ${ }^{1}$ Fakultas Pertanian, Universitas Andalas \\ ${ }^{2}$ Fakultas Pertanian, Universitas Islam Indragiri \\ *Corresponding author : zahlul_ikh@yahoo.com
}

\begin{abstract}
This This study aims to determine the best dose of $\mathrm{KCl}$ Fertilizer and Liquid Organic Fertilizer of coconut coir on the growth of sweet corn (zea mays saccaharata Sturt) in peat soils. This study used a non factorial randomized block design with 6 treatments and 4

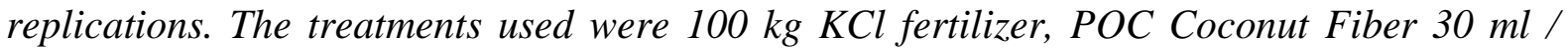
liter, $100 \mathrm{~kg} \mathrm{KCl}+P O C$ coconut coir fertilizer, $75 \mathrm{~kg} \mathrm{KCl}+\mathrm{POC}$ coconut coir fertilizer, 50 $\mathrm{kg} \mathrm{KCl}+P O C$ coconut coir fertilizer, $25 \mathrm{~kg} \mathrm{KCl}+\mathrm{POC}$ fertilizer coconut fiber. The parameters observed were plant height, number of leaves / plants, leaf area index, stem diameter, emergence, male and female flowers, observational data were analyzed using analysis of variance (ANOVA) and continued with HSD tukey test at 5\% confidence level. Based on the results of research that has been carried out, all treatments did not show a real effect on all parameters. Provision of coconut milk POC $30 \mathrm{ml} /$ water gives the best results on the growth of sweet corn.
\end{abstract}

Keywords: KCl fertilizer, liquid organic fertilizer, sweet corn

\section{PENDAHULUAN}

\subsection{Latar Bellakang}

Jagung (Zea mays L.) merupakan salah satu tanaman terpenting di dunia dan menduduki urutan ketiga setelah padi dan gandum. Di Amerika Tengah dan Amerika Selatan, tanaman jagung digunakan sebagai sumber karbohidrat utama dan menjadi alternatif sumber pakan ternak di Amerika Serikat. Di Indonesia (misalnya Madura dan Nusa Tenggara) jagung dijadikan sebagai makanan pokok, juga diambil minyaknya, diolah menjadi tepung dan bahan baku industri. Di Daerah Jawa Timur jagung yang dihasilkan pada umumnya dapat diserap seluruhnya untuk bahan baku pakan ternak (unggas). Begitu juga dengan daerah Nusa Tenggara Timur yang berpotensial untuk peternakan sapi, sangat ideal dikembangkan sebagai areal pertanaman jagung. Produk jagung maupun batangnya bisa digunakan untuk pakan ternak (Warisno, 1998). 
Kebutuhan jagung manis di Kabupaten Indragiri Hilir belum mampu untuk mencukupi kebutuhan konsumen karena belum ada petani yang membudidayakan jagung manis dengan tujuan bisnis, hal ini disebabkan produktifitas tanah gambut yang rendah. Anggapan petani tersebut selaras dengan pernyataan Euroconsult (1997) bahwa tanah gambut memiliki reaksi tanah yang masam, ketersediaan hara makro dan mikro yang rendah, asam organik yang dihasilkan tinggi sehingga meracuni tanaman, kapasitas tukar kation yang tinggi dan kejenuhi dan kejenuhan basa yang rendah serta drainase yang buruk menyebabkan tanah gambut memerlukan penanganan yang bijaksana.

Tanaman jagung adalah salah satu jenis bahan makanan yang mengandung karbohidrat yang dapat digunakan untuk menggantikan beras karena memiliki kalori yang hampir sama dengan kalori yang terkandung pada padi. Kandungan protein dalam biji jagung sama dengan biji padi serta dapat tumbuh pada berbagai macam tanah (AAK, 1993). Dengan adanya perkembangan teknologi pemuliaan tanaman jagung yang semakin maju, maka telah banyak dilepas berbagai jenis varietas unggul jagung. Jenis jagung yang kini banyak digemari adalah jagung manis atau sweet corn (Zea mays saccharata Sturt). Hal ini disebabkan karena jagung manis memiliki kelebihan terhadap rasa yang lebih manis dibandingkan dengan jagung biasa. Selain itu, umur produksinya lebih singkat, sehingga sangat menguntungkan dari segi ekonomi bahkan dari segi kesehatan sangat baik karena mengandung lemak yang rendah, kolesterol rendah, tanpa zat aditif, serat tinggi, karbohidrat tinggi, vitamin tinggi dan mengandung gula sukrosa yang aman bagi penderita diabetes. Perkembangan swalayan - swalayan baik besar maupun kecil meningkatkan permintaan sehingga pertanaman jagung manis semakin berkembang (Palungkun dan Asiani, 2004).

Hal ini berarti bahwa usaha pengembangan jagung manis di Indonesia mempunyai prospek yang cukup baik. Jagung dapat digunakan sebagai bahan pangan dipanen saat masih muda, biasanya dikonsumsi segar, dikalengkan dan dibekukan atau didinginkan (Klingman, 1965 cit. Mayadewi, 2007). Jagung manis mengandung kadar gula yang relatif tinggi, karena itu biasanya dipanen muda untuk dibakar atau direbus dan tak jarang juga dijadikan sayuran bahkan ada yang memakan mentah.

Produksi jagung manis di Indonesia masih rendah. Dengan rata rata 2,89 ton tongkol basah/hektar (Trubus, 1992), sedangkan produktivitas jagung manis di lembah Lockyer Australia dapat 
mencapai 7 - 10 ton tongkol basah/hektar (Lubach, 1980). Hal ini didukung juga oleh Rahmi dan Jumiati (2007) yang melaporkan bahwa produktivitas jagung manis di Kota Samarinda hanya mencapai angka 2,9 - 3,6 ton/hektar. Data ini menunjukkan bahwa produktivitas jagung manis berpotensi untuk ditingkatkan.

Produktivitas jagung manis yang rendah di Indonesia terutama disebabkan karena pembudidayaan dilakukan pada lahan berkesuburan tanah rendah, kadar hara rendah, bahan organik dalam tanah rendah dan $\mathrm{pH}$ tanah juga rendah. Untuk mengatasi masalah tersebut adalah dapat dilakukan dengan upaya pemupukan. Pemupukan bertujuan untuk memelihara atau memperbaiki kesuburan tanah sehingga tanaman dapat tumbuh lebih cepat, subur dan sehat. Pemupukan adalah suatu tindakan yang dilakukan untuk memberikan unsur hara kepada tanah dan atau tanaman sesuai yang dibutuhkan untuk pertumbuhannya. Pemakaian pupuk anorganik selain dapat meningkatkan produksi namun juga meninggalkan residu yang bisa merusak lingkungan yang berakibat tidak baik. Oleh karena itu dalam usaha pertanian saat ini lebih dianjurkan menggunakan pupuk organik. Pupuk organik mengandung bahan penting yang dalam menciptakan kesuburan tanah baik fisik, kimia dan biologis, dimana berfungsi sebagai pemantap agregat tanah di samping sebagai sumber hara penting tanah dan tanaman (Hakim, Lubis, Pulung, Nyakpa, Amrah dan Hong, 1987).

Usaha pengembangan pertanian di lahan gambut telah lama digalakkan, namun belum memberikan hasil yang maksimal. Hasil yang rendah tersebut erat kaitannya dengan kendala fisika dan kimia lahan, seperti dinamika air, dan kemasaman tanah. Unsur $\mathrm{K}$ merupakan faktor utama pada pertumbuhan tanaman jagung dilahan gambut. Menurut Purnamayani et al (2004), pada umumnya lahan gambut defisien $K$. Menurut Koretsky et al (2007) disebabkan proses mineralisasi bahan organik dalam lapisan gambut dapat mempengaruhi ketersediaan K.

Kalium diberikan ke tanah dalam bentuk pupuk. Pupuk $\mathrm{K}$ yang sering digunakan adalah $\mathrm{KCl}, \mathrm{KNO} 3$ atau K2SO4, ketiganya adalah pupuk sintetik. Sejak tahun 1968, di Indonesia terjadi peningkatan kebutuhan pupuk buatan secara tajam. Penggunaan pupuk buatan yang berkonsentrasi tinggi yang tidak proporsional akan berdampak pada peniympangan status hara dalam tanah (Notohadiprawiro, 1989), sehingga akan memungkinkan terjadinya kekurangan hara lain.

Untuk itu perlu upaya mencari sumber Kalium alternatif yang bersifat alami. Salah satunya melalui sisa-sisa 
tanaman. Aplikasi pupuk organik yang dikombinasikan dengan separuh takaran dosis standar pupuk kimia ( anorganik ) dapat menghemat biaya pemupukan . Hasil penelitian Nasaruddin dan Rosmawati (2011) pada tanaman kakao dengan memberikan pupuk cair dari fermentasi daun gamal, batang pisang dan sabut kelapa dengan perbandingan 1:1:1 dengan volume $30 \mathrm{ml} / \mathrm{l}$ air memberikan hasil terbaik pada parameter tinggi tanaman $(4,56)$, jumlah daun (5 helai) dan diameter batang bibit kakao.

Sabut kelapa merupakan bagian mesokarp berupa serat-serat kasar kelapa yang sangat melimpah di Kabupaten Indragiri Hilir. Ekawati dan Purwanto (2012) menjelaskan bahwa rata-rata kandungan kalium pada sabut kelapa berkisar $10,25 \%$. Menurut pusat penelitian tanah (1983) dalam Harjowigeno (1987), masih termasuk kategori tinggi sesuai dengan kriteria sifat kimia tanah.

\subsection{Tujuan Penelitian}

Untuk mengetahui pengaruh pemberian Pupuk KCl dan Pupuk Organik Cair (POC) Sabut Kelapa terhadap pertumbuhan Jagung Manis (Zea mays saccaharata) di tanah gambut.

\section{BAHAN DAN METODE}

\subsection{Lokasi dan Tempat}

Penelitian ini dilaksanakan sejak bulan September sampai Desember 2018. Penelitian dilaksanakan di lahan Fakultas Pertanian Universitas Islam Indragiri, Riau.

\subsection{Bahan dan Alat}

Bahan bahan yang akan digunakan dalam penelitian ini adalah benih jagung manis varietas pioneer, sabut kelapa, Pupuk anorganik (Urea, TSP, $\mathrm{KCl}$ ), dolomite Ripcord 3 EC, Dithane M-35. Sedangkan alat-alat yang digunakan dalam penelitian ini antara lain drum plastic, cangkul, sabit, hands prayer, gembor, kantong plastik, papan,timbangan elektrik, corong, alat tulis dan alat-alat lain yang menunjang penelitian seperti meteran, ember, kertas label, palu, gergaji, paku, karung, kayu, gelas ukur dan alat tulis

\subsection{Analisis Data}

Percobaan ini dilakukan dengan menggunakan Rancangan Acak Kelompok (RAK) non faktorial dengan 6 perlakuan dan 4 ulangan diantaranya:

$$
\begin{array}{ll}
1 & =100 \mathrm{~kg} \text { Pupuk KCl } \\
2 & =\text { POC Sabut Kelapa } 30 \mathrm{ml} / \text { liter air } \\
3 & =100 \mathrm{~kg} \text { Pupuk } \mathrm{KCl}+\text { POC sabut kelapa } 30 \mathrm{ml} / \mathrm{liter} \text { air } \\
4 & =75 \mathrm{~kg} \text { Pupuk } \mathrm{KCl}+\text { POC sabut kelapa } 30 \mathrm{ml} / \text { liter air }
\end{array}
$$


$5=50 \mathrm{~kg}$ Pupuk $\mathrm{KCl}+\mathrm{POC}$ sabut kelapa $30 \mathrm{ml} /$ liter air

$6=25 \mathrm{~kg}$ Pupuk $\mathrm{KCl}+$ POC sabut kelapa $30 \mathrm{ml} /$ liter air

Semua perlakuan diulang sebanyak 4 kali sehingga diperoleh 24 unit percobaan. Data yang diperoleh dianalisis dengan menggunakan Analisis Of Varian (ANOVA) dan apabila hasil analisis sidik ragam menunjukan pengaruh perlakuan berbeda nyata pada taraf kepercayaan $95 \%$ maka akan dilanjutkan dengan uji Tukey HSD pada taraf kepercayaan $95 \%$.

\subsection{Prosedur Penelitian}

Lahan yang akan digunakan sebagai tempat penelitian dibersihkan seluas 10 x 20 m. Plot-plot untuk penelitian disiapkan dengan luas $1,5 \times 3 \mathrm{~m}$ dengan jumlah 24 unit plot. Setiap plot dalam kelompok dipisahkan dengan parit dangkal dengan lebar $30 \mathrm{~cm}$ sedangkan setiap plot antar kelompok dipisahkan dengan parit dalam selebar $1 \mathrm{~m}$. Setelah plot-plot percobaan selesai dibuat maka dilakukan pengapuran menggunakan dolomite dengan dosis 10 ton per hektar. Pengapuran dilakukan 2 minggu sebelum tanam. Lubang tanam jagung dibuat dengan jarak $75 \mathrm{~cm}$ x $20 \mathrm{~cm}$ dengan kedalaman $3 \mathrm{~cm}$. Total lubang tanam dalam satu plot terdiri dari 28 lubang. Pemupukan dilakukan bersamaan dengan waktu penanaman. Pemupukan dilakukan dengan cara tugal disekitar lubang tanam. Pembuatan lubang tanam dilakukan dengan bersamaan dengan pembuatan lubang pupuk. Setiap lubang tanam dikelilingi 3 buah lubang, masing-masing lubang digunakan untuk pupuk urea, SP36 dan KCl. Setelah pembuatan lubang selesai, benih jagung yang sebelumnya direndam dengan air selama 12 jam dimasukan ke dalam lubang tanam sebanyak 2 biji perlubang tanam dan diikuti dengan pemupukan. Pupuk urea dan SP 36 diberikan sesuai dengan dosis rekomendasi. dosis pemupukan untuk budidaya tanaman jagung manis umumnya dianjurkan yaitu Urea sebanyak 450 kg/ha; SP-36 sebanyak $100 \mathrm{~kg} / \mathrm{ha}$; dan $\mathrm{KCl}$ sebanyak100 kg/ha. Pupuk $\mathrm{KCl}$ diberikan sesuai dengan perlakuan. Pupuk $\mathrm{P}$ dan $\mathrm{KCl}$ diberikan sekaligus pada saat tanam. Pupuk Urea diaplikasikan sebanyak 3 kali masing-masing $150 \mathrm{~kg} / \mathrm{ha}$ yaitu pada saat tanam, 3 Minggu Setelah Tanam (MST) dan 6 MST.Anonimus (2012). Penyulaman dilakukan pada saat tanaman berumur 7 - 14 hari. Penyulaman dilakukan pada tanaman yang tidak tumbuh dengan cara menanam kembali dengan benih yang baru. Penjarangan dilakukan setelah tanam berumur 14 hari. Penjarangan dilakukan pada tanaman jagung yang tumbuh lebih dari satu tanaman dalam satu lubang dengan cara 
menggunting tanaman jagung dan memelihara satu tanaman yang terbaik. Pemberian POC dilakukan 2 minggu setelah penanaman dan diulang setiap 2 minggu sekali selama 7 kali Aplikasi. POC diberikan pada tanaman jagung dengan cara disemprot ke permukaan bawah daun sampai pada bagian bawah daun basah yang di lakukan pada pagi hari antara pukul 07.00-10.00. Dosis POC diberikan ke tanaman dengan dosis $30 \mathrm{ml}$ POC sabut kelapa di campur 1 liter air. Pemeliharaan meliputi penyiraman, pengendalian gulma dan hama penyakit. Penyiraman dilakukan 2 kali sehari sampai kondisi tanah lembab. Pengendalian gulma dilakukan secara manual satu kali pada saat tanaman berumur 2 minggu. Pencegahan hama dilakukan dengan menyemprotkan Ripcord 3 EC dengan konsentrasi 1-2 cc/liter sedangkan pencegahan penyakit dilakukan dengan menyemprotkan Dithane M-35 dengan konsentrasi $2 \mathrm{~g} / \mathrm{l}$, dilakukan setiap 2 minggu sekali sejak tanaman berumur 14 hari setelah tanam.

\subsection{Parameter Pengamatan}

Pengamatan yang dilakukan adalah Tinggi Tanaman, Jumlah daun/tanaman (helai), Indeks luas daun (ILD), Diameter batang, Saat munculnya bunga jantan (tasseling) dan bunga betina (silking).

\section{HASIL DAN PEMBAHASAN}

\subsection{Tinggi Tanaman $(\mathrm{cm})$}

Tabel 1. Rataan Tinggi Tanaman $(\mathrm{cm})$

\begin{tabular}{ll}
\hline \multicolumn{1}{c}{ Perlakuan } & Tinggi Tanaman $(\mathrm{cm})$ \\
\hline $100 \mathrm{~kg}$ Pupuk KCl & $95.31 \mathrm{a}$ \\
POC sabut kelapa $30 \mathrm{ml} /$ liter air & $119.13 \mathrm{a}$ \\
$100 \mathrm{kgPupuk} \mathrm{KCl}+$ POC sabut kelapa & $90.50 \mathrm{a}$ \\
$75 \mathrm{kgPupuk} \mathrm{KCl}+$ POC sabut kelapa & $100.13 \mathrm{a}$ \\
$50 \mathrm{~kg}$ Pupuk KCl + POC sabut kelapa & $107.81 \mathrm{a}$ \\
$25 \mathrm{kgPupuk} \mathrm{KCl}+$ POC sabut kelapa & $127.19 \mathrm{a}$ \\
\hline
\end{tabular}

Pengaruh pemberian pupuk $\mathrm{KCl}$ dan pupuk organik cair (POC) sabut kelapa terhadap tinggi tanaman di tanah gambut diatas terlihat tidak memperlihatkan pengaruh yang nyata terhadap semua perlakuan, namun tinggi tanaman yang tertinggi terdapat pada 25 $\mathrm{kg} \mathrm{KCl+POC} \mathrm{sabut} \mathrm{kelapa} 30$ ml/1 liter air
$(127,19 \mathrm{~cm})$ dan tinggi tanaman yang terendah yaitu pada perlakuan $100 \% \mathrm{KCl}$ + POC sabut kelapa $30 \mathrm{ml} / 1$ liter air $(90,50 \mathrm{~cm})$. Dari data tinggi tanaman tersebut apabila dibandingkan dengan deskripsi tinggi tanaman yang berkisar 220 $\mathrm{cm}$, tinggi tanaman pada percobaan ini masih tergolong rendah. Rendahnya tinggi 
tanaman tersebut dibandingkan deskripsi banyak dipengaruhi oleh ketersediaan hara pada tanah, efesiensi pemupukan yang diberikan, lingkungan dimedia tumbuh yang ideal bagi tanaman jagung.

Pada perlakuan POC sabut kelapa dan $25 \mathrm{~kg}$ Pupuk KCl+POC sabut kelapa merupakan nilai tertinggi dibandingkan dengan parameter lain walaupun tidak memperlihatkan pengaruh yang nyata pada pertumbuhan tinggi tanaman hal ini disebabkan oleh peran dari POC yang banyak menyediakan unsur-unsur hara sehingga mampu mengembalikan keseimbangan tanah dan mempertahankan unsur hara lebih lama yang dapat mendukung pertumbuhan tanaman jagung secara optimal. Hal ini sejalan dengan Fattah (2010) yang menyatakan bahwa pupuk organik berperan dalam menyediakan unsur hara mineral dan asam amino bagi tanaman, mengembalikan keseimbangan tanah dan mempertahankan unsur hara lebih lama sehingga dapat mendukung pertumbuhan tanaman secara optimal.

Tingginya rata-rata tinggi tanaman pada perlakuan yang menggunakan pada $25 \mathrm{~kg} \mathrm{KCl+POC} \mathrm{sabut} \mathrm{kelapa} \mathrm{dan} \mathrm{POC}$ sabut kelapa hal ini disebabkan oleh efesiensi serapan hara makro terutama yang lebih tinggi dibandingkan perlakuan lainnya, namun dilihat dari Tabel 1. bahwa semakin rendah pada pemberian $\mathrm{KCl}$ maka terlihat peningkatan tinggi tanaman jagung manis, walaupun tidak memperlihatkan pengaruh yang nyata. jika dibandingkan tanaman kontrol dengan POC sabut kelapa (30 ml/ 1 liter air) terlihat bahwa perlakuan POC sabut kelapa (30 ml/ 1 liter air) lebih tinggi dibandingkan tanaman kontrol (100 $\mathrm{kg} \mathrm{KCl}$ ) hal ini disebabkan karena pengaruh dari POC sabut kelapa yang mampu meningkatkan unsur hara pada tanaman sehingga tinggi tanaman akan berkembang dengan baik. Pada POC sabut kelapa selain unsur $\mathrm{K}$ juga terdapat unsur $\mathrm{N}$ dan $\mathrm{P}$ walaupun pada unsur $\mathrm{N}$ dan $\mathrm{P}$ sedikit di bandingkan dengan unsur $\mathrm{K}$ dimana unsur $\mathrm{N}$ dan $\mathrm{P}$ untuk merangsang pertumbuhan tanaman terutama pada pase vegetatif. Dan dengan pemberian POC sabut kelapa $30 \mathrm{ml} /$ liter air dapatmempengaruhi pertumbuhan tanaman jagung sebagai pengurai bahan organik menjadi unsur hara yang mengandung unsur hara makro dan mikro sehingga mudah diserap tanaman. Menurut Lakitan (2012) cukupnya kebutuhan hara tanaman baik unsur hara makro maupun mikro akan meningkatkan pertumbuhan tanaman dan sebaliknya, jika kebutuhan hara tanaman kurang mengakibatkan pertumbuhan tanaman terhambat. 


\subsection{Jumlah Daun/Tanaman (helai)}

Tabel 2. Rataan Jumlah Daun

\begin{tabular}{lc}
\hline \multicolumn{1}{c}{ Perlakuan } & Jumlah Daun (helai) \\
\hline $100 \mathrm{~kg}$ Pupuk KCl & $12.375 \mathrm{a}$ \\
POC sabut kelapa $30 \mathrm{ml} /$ liter air & $13.250 \mathrm{a}$ \\
$100 \mathrm{kgPupuk} \mathrm{KCl}+$ POC sabut kelapa & $11.750 \mathrm{a}$ \\
$75 \mathrm{kgPupuk} \mathrm{KCl}+$ POC sabut kelapa & $12.500 \mathrm{a}$ \\
$50 \mathrm{~kg}$ Pupuk KCl + POC sabut kelapa & $13.000 \mathrm{a}$ \\
$25 \mathrm{kgPupuk} \mathrm{KCl}+$ POC sabut kelapa & $13.250 \mathrm{a}$ \\
\hline
\end{tabular}

Pengaruh pemberian pupuk $\mathrm{KCl}$ karena didalam POC sabut kelapa dan pupuk organik cair (POC) sabut kelapa terhadap jumlah daun/tanaman di mempunyai unsur $\mathrm{N}$, $\mathrm{P}$ dan $\mathrm{K}$ sehingga lebih lengkap dibandingkan tanaman tanah gambut diatas terlihat tidak kontrol yang hanya mempunyai unsur hara memperlihatkan pengaruh yang nyata terhadap semua perlakuanjumlah daun/tanaman, namun jumlah daun/tanaman yang terbanyak terdapat pada POC sabut kelapaadalah (13.250 helai ) dan jumlah daun/tanaman yang sedikit yaitu pada perlakuan $100 \mathrm{~kg} \mathrm{KCl}+$ POC sabut kelapa (11.750 helai), selanjutnya apabila pemberian pupuk $\mathrm{KCl}$ dosisnya diturunkan terlihat peningkatan terhadap jumlah daun tanaman jagung manis walaupun tidak memperlihatkan pengaruh yang nyata pada peralakuan. Sedangkan pada perlakuan POC sabut kelapa dibandingkan dengan25 kg $\mathrm{KCl}+\mathrm{POC}$ sabut kelapa memiliki nilai yang sama terhadap jumlah daun/tanaman hal ini karena dipengaruhi pemberian POC sabut kelapa dapat memperbaiki K. Nasaruddin (2010) juga menyatakan bahwa pemupukan lewat daun lebih cepat penyerapan haranya dibandingkan dengan lewat akar. Pupuk daun dapat memberikan menambah persediaan hara pada tanaman, walaupun hara diberikan relatif sedikit, tetapi bersifat kontinyu. Pemberian pupuk sangat erat kaitannya dengan fase pertumbuhan vegetatif. Nitrogen merupakan unsur hara utama tanaman bagi pertumbuhan tanaman, pada umumnya sangat diperlukan untuk pembentukan atau pertumbuhan bagian-bagian vegetatif tanaman, seperti daun, batang dan akar. Fosfor dapat mempercepat serta memperkuat per-tumbuhan tanaman muda menjadi tanaman dewasa. Sedangkan kalium berperan dalam pembentukan protein dan karbohidrat.

pertumbuahan tanaman pada pase vegetatif 


\subsection{Indeks Luas Daun (ILD) (cm)}

Tabel 3. Rataan Indeks Luas Daun (cm)

\begin{tabular}{lc}
\hline \multicolumn{1}{c}{ Perlakuan } & Rata-rata $(\mathrm{cm})$ \\
\hline $100 \mathrm{~kg}$ Pupuk KCl & $26.595 \mathrm{a}$ \\
POC sabut kelapa 30 ml/liter air & $29.090 \mathrm{a}$ \\
$100 \mathrm{kgPupuk} \mathrm{KCl}+$ POC sabut kelapa & $23.197 \mathrm{a}$ \\
$75 \mathrm{kgPupuk} \mathrm{KCl}+$ POC sabut kelapa & $21.900 \mathrm{a}$ \\
$50 \mathrm{~kg}$ Pupuk KCl + POC sabut kelapa & $27.155 \mathrm{a}$ \\
$25 \mathrm{kgPupuk} \mathrm{KCl}+$ POC sabut kelapa & $30.957 \mathrm{a}$ \\
\hline
\end{tabular}

Pengaruh pemberian pupuk $\mathrm{KCl}$ dan pupuk organik cair (POC) sabut kelapa terhadap jumlah daun/tanaman di tanah gambut diatas terlihat tidak memperlihatkan pengaruh yang nyata terhadap indeks luas daun (ILD), namun indeks luas daun (ILD) yang tertinggi terdapat pada $25 \mathrm{~kg} \mathrm{KCl+POC} \mathrm{sabut}$ kelapa adalah (30.957) $\mathrm{cm}$. Dan indeks luas daun (ILD) yang terendah yaitu pada perlakuan $75 \mathrm{~kg} \mathrm{KCl}+$ POC sabut kelapa adalah $(21.900) \mathrm{cm}$.

Rendahnya nilai rata-rata pada indeks luas daun ini desebabkan oleh ketersediaan kalium belum mampu memberikan pertumbuhan yang maksimal sehingga pada pertumbuhan terganggu sehingga apabila pada tanaman kekurangan unsur kalium maka daun-daun berubah jadi kering terutama pada daun yang tua, batangnya menjadi lemah dan pendek sehingga tanaman menjadi kerdil. Hal ini sejalan dengan pendapat Yusuf (2009) pada pertumbuhan tanaman jagung dibutuhkan unsur hara kalium yang banyak, bila kekurangan unsur kalium maka daun-daun berubah menjadi kering atau berkerut terutama pada daun yang tua, batangnya menjadi lemah dan pendekpendek sehingga tamanan terlihat kerdil.

Sedangkan untuk perlakuan POC sabut kelapa dengan $25 \mathrm{~kg}$ pupuk $\mathrm{KCl}+\mathrm{POC}$ sabut kelapa merupakan nilai tertinggi dibandikan perlakuan yang lain hal ini disebabkan dari peran POC sabut kelapa yang banyak mengandung unsur hara seperti N,P dan $\mathrm{K}$, sedangkan $\mathrm{KCl}$ hanya terdapat unsur hara $\mathrm{K}$ saja, sehingga ketersedian hara pada tanaman belum cukup terpenuhi. Meskipun tidak memperlihatkan pengaruh yang nyata, namun terdapat nilai rata-rata yang berbeda pada masing-masing perlakuan, karena unsur hara Kalium yang diberikan tidak mampu bekerja dengan baik.Semakin tinggi diberikan unsur $\mathrm{K}$ pada tanaman jagung tidak menunjukan pengaruh yang nyata pada semua perlakuan hal tersebut dipengaruhi oleh unsur K yang berlebihan sehingga tanaman kurang berkembang 
secara optimal.Hal ini sesuai dengan pendapat Setyamidjaja (1996), bahwa tiaptiap unsur hara mempunyai fungsi tersendiri dan dapat mempengaruhi proses tertentu di dalam pertumbuhan dan perkembangan tanaman, baik salah satu atau beberapa unsur hara tidak berada dalam jumlah cukup atau salah satu unsur hara yang berlebihan dan kekurangan, maka tanaman akan menunjukkan gejala pertumbuhan yang kurang optimal.

Tingginya rata-rata indeks luas daun pada perlakuan $25 \mathrm{~kg} \mathrm{KCl}+\mathrm{POC}$ sabut kelapa disebabkan oleh pemberian pupuk $\mathrm{KCl}$ pada tanaman jagung mampu mencukupi kebutuhan unsur $\mathrm{K}$ karena ditambahnya dengan POC sabut kelapayang mampu memberikan kesuburan yang baik. Oleh sebab itu dengan pemberian POC sabut kelapa dapat meberikan pengaruh terhadap ketersedian hara pada tanaman sehingga dapat memberikan dampak yang baik terhadap kesuburan tanah, Hakim, et al,(1988).

Tinggi tanaman dan diameter batang juga mepengaruh oleh luas daun, semakin tinggi tanaman dan diameter batang yang besar, maka pada luas daun akan sempurna. Selain itu luas daun dipengaruhi oleh ketersediaan unsur hara hal ini sesuai dengan pendapat Wibowo dkk.,(2012). Luas daun juga sangat dipengaruhi oleh ketersediaan unsur hara. Salisbury dan Ross (1995) menyatakan bahwa penyerapan unsur hara terutama unsur hara nitrogen berpengaruh terhadap pembentukan luas daun.

\subsection{Diameter Batang (cm)}

Tabel 4. Berat Produksi (gr)

\begin{tabular}{lc}
\hline \multicolumn{1}{c}{ Perlakuan } & Rata-rata \\
\hline $100 \mathrm{~kg}$ Pupuk KCl & $1.6000 \mathrm{a}$ \\
POC sabut kelapa $30 \mathrm{ml} /$ liter air & $1.7625 \mathrm{a}$ \\
$100 \mathrm{kgPupuk} \mathrm{KCl}+$ POC sabut kelapa & $1.6375 \mathrm{a}$ \\
$75 \mathrm{kgPupuk} \mathrm{KCl}+$ POC sabut kelapa & $1.4750 \mathrm{a}$ \\
$50 \mathrm{~kg}$ Pupuk $\mathrm{KCl}+$ POC sabut kelapa & $1.7375 \mathrm{a}$ \\
$25 \mathrm{kgPupuk} \mathrm{KCl}+$ POC sabut kelapa & $1.7750 \mathrm{a}$ \\
\hline
\end{tabular}

Pertumbuhan jagung manis dengan pemberian kombinasi pupuk $\mathrm{KCl}$ dan pupuk organik cair (POC) sabut kelapa di tanah gambut tidak memperlihatkan pengaruh yang nyata terhadap diameter batang, namun diameter batang yang tertinggi terdapat pada $25 \mathrm{~kg} \mathrm{KCl}+\mathrm{POC}$ sabut kelapa (30 ml/1 liter air) adalah (1.7750) $\mathrm{cm}$. Dan diameter batang yang terendah yaitu pada perlakuan $75 \mathrm{~kg} \mathrm{Kcl} \mathrm{+}$ 
POC sabut kelapa (30 ml/1 liter air) adalah $(1.4750) \mathrm{cm}$. Dari data yang diperoleh tersebut bahwa rata-rata diameter batang berkisar 1,4750-1,7750 cm

Secara angka diameter batang yang tertinggi adalah pada perlakuan $25 \mathrm{~kg}$ $\mathrm{KCl}+\mathrm{POC}$ sabut kelapa (30 ml/1 liter air), serta jika dilihat dari segi ekonomis penggunaan KCL bahwa perlakuan POC sabut kelapa $30 \mathrm{ml} / 1$ liter air merupakan yang terbaik karena tidak memakai pupuk $\mathrm{KCl}$ lagi meskipun pada semua perlakuan tidak memperlihatkan pengaruh yang nyata pada diameter batang. Rendahnya nilai rata-rata diameter batang tersebut dipengaruhi oleh pemberian pada $\mathrm{KCl}$ dan POC belum mampu memberikan hasil optimal sehingga pada ketersedian unsur hara yang berasal dari POC sabut kelapa tersebut masih tergolong rendah oleh karena itu $\mathrm{KCl}$ dan POC sabut kelapa yang berasal dari tanah terikat oleh unsur hara lain sehingga proses metabolisme serta pembelahan sel akan terganggu, Widjaya dan Sudjadi (1987). Disamping itu pada Faktor luar lainnya yang mempengaruhi adalah suhu. Suhu yang dimaksud adalah suhu udara sekitar, panas atau tidaknya suhu bisa secara tidak langsung mempengaruhi kerja kalium.

\subsection{Muncul Bunga Jantan ( tasseling ) dan Bunga Betina (silking)}

Tabel 5. Rataan Jumlah Daun

\begin{tabular}{ll}
\hline \multicolumn{1}{c}{ Perlakuan } & B. Jantan(hst)B. Betina(hst) \\
\hline $100 \mathrm{~kg}$ Pupuk KCl & $54.500 \mathrm{a} 58.000 \mathrm{a}$ \\
POC sabut kelapa $30 \mathrm{ml} /$ liter air & $52.500 \mathrm{a} 56.500 \mathrm{a}$ \\
$100 \mathrm{kgPupuk} \mathrm{KCl}+$ POC sabut kelapa & $54.250 \mathrm{a} 58.750 \mathrm{a}$ \\
$75 \mathrm{kgPupuk} \mathrm{KCl}+$ POC sabut kelapa & $54.000 \mathrm{a} 57.750 \mathrm{a}$ \\
$50 \mathrm{~kg}$ Pupuk KCl + POC sabut kelapa & $54.000 \mathrm{a} 57.250 \mathrm{a}$ \\
$25 \mathrm{kgPupuk} \mathrm{KCl}+$ POC sabut kelapa & $53.000 \mathrm{a} 56.000 \mathrm{a}$ \\
\hline
\end{tabular}

Pertumbuhan jagung manis dengan pemberian kombinasi pupuk $\mathrm{KCl}$ dan pupuk organik cair (POC) sabut kelapa di tanah gambut tidak memperlihatkan perbedaan yang nyata terhadap muncul bunga jantan dan bunga betina, namun muncul bunga jantan yang tercepat terdapat pada POC sabut kelapa $(30 \mathrm{ml} / 1$ liter air) tanpa $\mathrm{KCl}$ adalah (52.500) hst, dan muncul bunga jantan yang terlama yaitu pada perlakuan $100 \mathrm{~kg} \mathrm{KCl}$ tanpa sabut kelapa $30 \mathrm{ml} / 1$ liter air adalah (54.500) hst. Sedangkan muncul bunga betina yang tercepatperdapat pada $25 \mathrm{~kg}$ $\mathrm{KCl}+\mathrm{POC}$ sabut kelapa (30 ml/1 liter air) adalah ( 56.000) hst, dan yang terlama muncul bunga betina terdapat pada $100 \mathrm{~kg}$ $\mathrm{KCl}$ tanpa POC sabut kelapa adalah (58.750) hst. 
Pemberian POC sabut kelapa (30 ml/1 liter air) adalah memberikan umur keluar bunga jantan yang tercepatkarena, dipengaruhi oleh ketersedian unsur hara pada POC dapat memberikan dorongan terhadap pertumbuhan tanaman yang didalamnya tersedia oleh unsur makro seperti $\mathrm{N}$ dan $\mathrm{P}$ serta unsur hara $\mathrm{K}$ yang banyak terdapat pada POC sabut kelapa sehingga pertumbuhan tanaman baik dan sempurna. Sedangkan pada muncul bunga betina yang tercepat adalah pada perlakuan $25 \mathrm{~kg} \mathrm{KCl}+\mathrm{POC}$ sabut kelapa $(30 \mathrm{ml} / 1$ liter air) hal ini dikarenakan selain peran POC sabut kelapa, peran unsur $\mathrm{K}$ mempengaruhi pada proses pembungaan tanaman jagung.

Pada saat tanaman jagung manis memasuki fase pembungaan dibutuhkan kondisi lingkungan yang cukup air. Menurut Rahmat Rukmana (1997) curah hujan yang ideal untuk tanaman jagung adalah $100-200 \mathrm{~mm}$ per bulan. Berdasarkan percobaan yang dilakukan, tanaman jagung manis memasuki fase pembungaan pada akhir bulan Maret sampai awal bulan Juni dimana rata-rata curah hujannya cukup tinggi sehingga merupakan kondisi yang optimum untuk proses pembungaan. Darjanto dan Satifah (1992) menyatakan bahwa untuk pembentukan bunga yang berpengaruh penting adalah faktor genetik disamping faktor lingkungan seperti suhu, cahaya dan air. Selain itu pada pase vegetatif pertumbuhan juga sangat mempengaruhi pada munculnya bunga jantan dan betina contohnya pada tinggi tanaman, dimeter batang dan luas daun sangat berpengaruh karena pada pase tersebut tanaman mampu berproduksi apabila tanaman tersebut tumbuh dengan baik dan sempurna. Sebaliknya bila tanaman tersebut tidak mampu berproduksi dengan baik atau terganggu pada pertumbuhannya maka tanaman tersebut akan kerdil sehingga pada pembungaan akan terganggu.

\section{KESIMPULAN}

Pemberian pupuk $\mathrm{KCl}$ dan $\mathrm{POC}$ sabut kelapa tanah gambut tidak memperlihatkan pengaruh yang nyata terhadap pertumbuhan jagung manis di lahan gambut. Perlakuan yang terbaik untuk pertumbuhan jagung manis adalah pemberian POC sabut kelapa $30 \mathrm{ml} / \mathrm{liter}$ air.

\section{DAFTAR PUSTAKA}

AAK, 1993. Teknik Bercocok Tanam Jagung. Kanisius. Jogyakarta.

Ekawati, I., dan Purwanto, Z,. 2012. Potensi Abu Limbah Pertanian Sebgai Sumber Alternatif Unsur Hara Kalium, Kalsium, dan Magnesium untuk Menunjang kelestarian Produksi Tanaman. Fakultas Pertanian Univeritas Wiraraja. Sumenep.

Euroconsult. 1997. Nation - wide Study

Coastal and Near - coastal 
Swamps Land in Sumatra, Kalimantan and Irian jaya. Executive Report. Dir. Gen. of Water Res. Development, Min. of

Public Work, Jakarta and Euroconsult, Arnhem/BIEC. Bandung.

Hakim,N., A.M. Lubis, M.A. Pulung, M.Y. Nyakpa, M.G. Amrah dan G.B. Hong. 1988 .Pupuk dan Pemupukan. BKSPTNBarat/WUAE Project. Palembang. Koretsky, C.M., M. Haveman, L. Beuving, A. Cuellar, T. Shattuck, M. Wagner. 2007. Spatial Variation Of Redox And Trace Metal Geochemistry In A Minerotrophic Fen. Biogeochemistry 86:33-62.

Lakitan, Benyamin. 2012. Dasar-dasar Fisiologi Tumbuhan. Jakarta: Rajawali press.

Lubach, G. W. 1980. Growing Sweet Corn For Processing Queensland. Agric. J. 106 (3): 218-230.p

Mayadewi, N. N. A. 2007. Pengaruh Jenis Pupuk Kandang dan Jarak Tanam Terhadap Pertumbuhan Gulma dan Hasil Jagung Manis. Jurusan Budidaya Pertanian. Vol 26 (4) : 153 - 159 (2007). Fakultas Pertanian Unud, Denpasar.

Notohadiprawiro, T. 1989. Dampak Pembangunan Pada Tanah, Lahan dan Tata Guna Lahan, PSL. UGM. Yogyakarta.

Notohadiprawiro, T., 2006. Pola Kebijakan Pemanfaatan Sumberdaya Lahan Basah, Rawa dan Pantai. Gadjah Mada University Press, Yogyakarta.

Palungkun, R., 2004. Aneka Produk Olahan Kelapa. Penebar Swadaya, Jakarta

Rahmat Rukmana. 1997. Usaha Tani Jagung. Penerbit Kanisius. Jogjakarta

Warisno. 1998. Jagung Hibrida. Kanisius. Yogyakarta.
Wibowo, Agung Edy, 2012, Aplikasi Praktis SPSS Dalam Penelitian, Gava Media, Yogyakarta

Yusuf, H. 2009. Pengaruh Naungan Dan Tekstur Tanah Terhadap Pertumbuhan Dan Produksi Bawang Sabrang (Eleutherine americana MERR.), USU Repository 2009 